\title{
Micro Combined Heat and Power Systems - Evaluation of a Sample Application
}

\begin{abstract}
Anayo A. Ezeamama ${ }^{1} \&$ Eike Albrecht ${ }^{1}$
${ }^{1}$ Department of Civil Law and Public Law with References to the Law of Europe and the Environment, Faculty of Business, Law and Social Sciences, Brandenburg University of Technology, Cottbus-Senftenberg, Erich-Weinert-Strasse 1, 03046 Cottbus, Germany

Correspondence: Anayo A. Ezeamama, Department of Civil Law and Public Law with References to the Law of Europe and the Environment, Faculty of Business, Law and Social Sciences, Brandenburg University of Technology, Cottbus-Senftenberg, Erich-Weinert-Strasse 1, 03046 Cottbus, Germany. E-mail: ezeamana@b-tu.de
\end{abstract}

Received: May 10, 2018

Accepted: June 5, 2018

Online Published: June 12, 2019

doi:10.5539/enrr.v9n3p1

URL: https://doi.org/10.5539/enrr.v9n3p1

\begin{abstract}
The growing need for a secure, cost-effective, less polluting and efficient form of energy has contributed to an increasing interest in the use of micro combined heat and power (MCHP) systems. In this paper, the environmental performance and economic feasibility of a $1 \mathrm{~kW}_{\mathrm{e}}$ internal combustion engine (ICE) MCHP system in a one-family house was assessed and compared with the baseline scenario were residential energy demands are met with grid electricity and natural gas fired condensing boilers. The result of the analysis shows that MCHP systems present opportunities for savings in energy costs. Based on a social discount rate (SDR) of $5 \%$ and a calculated 3259 operating hours, a simple payback period of about 4.8 years was derived as the time needed to recover the extra investment cost of the ICE unit. The result of the sensitivity analysis reveals that, both the running hours and price of electricity have significant effects on the payback period of the project. Considering the end of useful life period of the systems, MCHP offer a good replacement for conventional gas boilers of $90 \%$ efficiency. However, their high initial costs (when compared to high efficiency condensing boilers), could be seen as the major factor hampering market diffusion. Also, considering the optimal environmental benefits, MCHP system produced more on-site $\mathrm{CO}_{2}$ emissions in reference to the condensing boiler but generally, annual $\mathrm{CO}_{2}$ emission is reduced by about $38 \%$ when compared to the overall separate generation of heat and power scenario.
\end{abstract}

Keywords: Micro-combined heat and power (MCHP), Heat, Power, Energy, Emission

\section{Introduction}

Measures geared towards ensuring security of energy supply at reduced cost and with minimum environmental consequences play leading roles in the energy policies of most developed nations. Such measures include technological development of advanced and efficient infrastructures, related policies to improve supply- and demand-side energy management, renewable energy, and decentralized generation. Energy is needed for electricity and heat generation especially in the building sector. One of the major short-comings of the conventional method, where electricity and heat are produced and distributed via separate mechanisms, is that, due to the inability to transport heat over long distances, the enormous amount of heat produced is not utilized purposefully but rather lost as waste heat to the environment. According to the United States (US) Environmental Protection Agency (EPA), this reduces the efficiency of grid electricity generation to about 33 per cent (EPA, 2013). Conventional gas fired boilers generate heat for space heating and hot water with an efficiency of over 90 per cent; however, due to electricity transmission losses, the overall efficiency of the entire system is estimated at 51 per cent (EPA, 2013).

Studies by “Arbeitsgemeinschaft für Sparsamen und Umweltfreundlichen Energieverbrauch" (ASUE) show that in Germany, space heating and hot water production accounts for more than one third of all primary energy consumption and that in residential buildings, about 90 per cent of the final energy is used for producing heat and domestic hot water (ASUE, 2008, 5). Furthermore, studies have shown that indirect emissions from electricity generation in Germany, contribute more than half of total emissions from building energy use (Amecke et al., 2013). Undoubtedly, measures geared towards reducing primary energy consumption in this 
sector has good potential for energy savings, for reducing carbon emissions associated with energy production and for realizing other socio-economic benefits.

Cogeneration is the production of heat and electricity simultaneously in a single, integrated system using one fuel source (Ren, Gao, \& Ruan, 2007). Natural gas and renewables are some of the various primary energy sources for a cogeneration system. The implementation of small-scale CHP systems (MCHP) for residential space heating and hot water production is becoming popular in Europe especially in Germany, United Kingdom and the Netherlands (COGEN Europe, 2005). This system mainly meets the need for heat generation first with the secondary product being electricity. Reports of the European Commission (EC) show that MCHP systems are considered future replacement of the present domestic heating systems with production of heat and power on a small scale, typically with electric capacities of less than $50 \mathrm{~kW}$ (EC, 2004). The electricity produced through this means, through grid integration, can also be sold back to the power grid. The main advantage of this cogeneration system is that the heat produced during electricity generation that would have instead been wasted in a conventional system is captured and utilized. The overall system efficiency of the cogeneration system is estimated at approximately, 80 per cent (EPA, 2013) (Note 1). European Union (EU) policies on energy acknowledges the use of MCHP as a significant means of reducing emissions in the residential sector and thus an avenue of achieving Kyoto target (EC, 2004; Uyterlinde, van Sambeek, \& Cross, 2002). Also, the International Energy Agency (IEA) / Energy Conservation in Buildings and Community systems (ECBCS) Annex 42 indicates that, "The concurrent generation of electricity and heat from a single fuel source can reduce primary energy consumption and associated greenhouse gas emissions" (IEA/ECBCS Annex 42 2004). Economically, it is believed that cogeneration of heat and power could assist end users in saving energy and associated cost since transmission and distributional charges are avoided.

This study attempts to perform an empirical assessment of the energy costs and emissions savings potentials of MCHP systems with a German residential apartment as a case study. A literature review has been conducted to gain basic background knowledge of this technology and to aid this author to establish a theoretical-based hypothesis in terms of system use. Following this will be an assessment of the environmental compatibility of this system and economic benefits to end-users. It is thus, the intention of this author to establish if this system presents any economic prospects to end users and the feasibility of serving as a viable replacement of the current conventional method of heat and electricity production especially in old and existing buildings.

\section{Aim and Objective}

This paper is structured to assess the operational performance of an installed and functioning MCHP system for the provision of space heating and electricity in a one-family house apartment and to compare it with the conventional method of heat and electricity supply. The basis of this assessment is to establish the actual potential of MCHP systems in terms of its possible economic benefits to end users and the environment as a whole and not to rely only on theory-based expectations. In achieving this aim, the paper establishes empirical findings in support of policies to encourage the use of MCHP systems, over the condensing gas boilers, as a means of reducing energy consumption and emissions from the residential sector. The research is mainly focused on assessing the performance of MCHP system in old and existing buildings which constitutes bulk of Germany building stock. Germany has a relatively old building stock, long building lifetime, low construction rate of new buildings; and despite the low construction rates, policy that enforces reduction in thermal energy demand in new buildings (the Energy Savings Ordinance - EnEv) prevails (Amecke et al., 2013). MCHP systems may not be economically viable in buildings with low thermal energy demand. Also, the research was not intended to compare energy cost and emissions savings potentials of MCHP systems with other residential energy efficiency measures.

\section{Research Methodology}

Annual electricity consumption and its related cost for a single family house (with three occupants) in Germany was estimated based on published mean values for a similar house from the Stadtwerke Cottbus (SWC) utility (SWC, 2005). Also, information on gas consumption (per $\mathrm{m}^{2}$ and year, using the conventional gas boilers) for both heating and hot water production and associated unit cost per $\mathrm{kWh}$ as published by the SWC (2005), was used to compute annual heat consumption (in $\mathrm{kWh}$ ) in the selected case study and the corresponding annual heating costs. The percentage distribution of the energy mix for grid electricity generation in the region and corresponding $\mathrm{CO}_{2}$ emission in total was adopted from the SWC utility (Table 3). National support scheme as published by the Federal Office of Economics and Export Control (Bundesamt für Wirtschaft Und Ausfuhrkontrolle - BAFA) (which includes, average value in 2011 for feed-in-tariffs at $5.45 €$ cent $/ \mathrm{kWh}$, the electricity bonus payment for cogeneration with efficiency of greater than $70 \%$ at $5.11 € \mathrm{cent} / \mathrm{kWh}$ and the gas 
subsidy payment of $0.55 €$ cent $/ \mathrm{kWh}$ ) that rewards the positive externalities of CHP usage in Germany was implemented (BAFA, 2012). This payment structure applies to MCHP with electricity capacity up to $50 \mathrm{~kW}_{\mathrm{e}}$ and is applicable as at the period this research was carried out. However, the amount and the duration of payment for the electricity generated now depend on the date of commencement of the continuous operation of the CHP plant. This is as a result of the revised payment structure which took effect from 1 January, 2015 (BAFA, 2012)

A detailed literature review was carried out to present a theoretical basis relevant in gathering vital information on the state-of-art residential MCHP systems. As a result, the ECOWILL model $1 \mathrm{~kW}_{\mathrm{e}}$ ICE micro CHP unit with a thermal output of $3.5 \mathrm{kWh}$ was considered suitable for a single family house (ASUE 2008, 14). Information on system parameters, (e.g. investment and operational costs, etc.), of the selected MCHP unit was adopted from previous studies (Ren et al., 2007; Houwing, 2010) (Table 1). The table also includes price for the currently used high efficiency condensing boilers for comparison purposes. Based on expert knowledge gained from consulted literatures, careful assumptions were made to generate a model for a cost and benefit analysis of system operation for both cogeneration and separate heat and power production scenarios. It is assumed that the use of the MCHP system will generate equal benefits for each of the ten year useful life period of the system beginning at $t=1$ (Table 2). A simple payback period needed to recover the extra cost on investment for a MCHP system was derived by calculating the present values (value at $t=0$ ) of the benefits of plant use. The payback period gives an insight on the economic feasibility of the system considering its end of useful life period; the lower the return on investment, the less is the financial risk and the more attractive to customers.

Table 1. System parameters " 2007 "

\begin{tabular}{lc}
\hline Power output & $1 \mathrm{kWe}$ \\
\hline Thermal output & $3.25 \mathrm{kWt}$ \\
Electrical efficiency & $20 \%$ \\
Total efficiency & $85 \%$ \\
Maintenance cost & $1.7 €$ cent $/ \mathrm{kWhe}$ \\
Boiler price & $€ 1500-3000$ \\
ICE MCHP & $€ 5500-7000$ \\
Extra investment cost for MCHP & $€ 4000$ \\
Expected lifetime & 10 years \\
\hline
\end{tabular}

Characteristics of Honda Ecowill MCHP model. Source: Ren et al., 2007 Study of different micro CHP alternatives for residential application, Japan; Houwing, 2010 Smart heat and power: utilizing the flexibility of micro cogeneration, Next generation infrastructures foundation, Delft, the Netherlands. ASUE, 2008 Power-generating heating systems: opportunities for improving energy efficiency, Kaiserslautern.

For the environmental assessment, data on emission factor for the combustion of natural gas was adopted from the Intergovernmental Panel on Climate Change (IPCC) Guidelines for National Greenhouse Gas Inventories (2006) and the emission factor value was used to estimate the total annual $\mathrm{CO}_{2}$ emission from the cogeneration system (Table 5). Direct quantitative comparison with the information gathered on $\mathrm{CO}_{2}$ emission rate of grid electricity mix was used to compute the emission reduction ratio (ERR) or the emission savings with a MCHP system and this gives an insight on the overall emission savings potential of the MCHP system in comparison with the conventional method of heat and power generation.

\subsection{Scenario Description}

A single-family house has been modeled to represent a typical Germany residence, having a total floor area of approximately $120 \mathrm{~m}^{2}$ with three persons as inhabitants. The major energy demand in this one-family apartment is divided into electrical and thermal demand. Thermal demand consists of space heating and hot water (hot water at $\left.60^{\circ} \mathrm{C}\right)$. The average warm water demand is 40 liters per person per day $(43,800$ liters per year) which corresponds to typical demand according to 2015 published data (Paschotta, 2016). The annual heat demand is estimated as $10,590 \mathrm{kWh}\left(88.25 \mathrm{kWh}\right.$ per $\mathrm{m}^{2}$ and year). According to the Federal Ministry of Environment (Bundesministerium für Umwelt - BMU), this value is in the lower middle range of the statistical value for Cottbus (BMU, 2009) and thus, can be interpreted to represent a thermally upgraded detached house. Average electricity usage is estimated as $3,750 \mathrm{kWh}$ per year and is deemed a good average value considering German published average values in 2015 (SWC, 2015). 
A micro cogeneration unit is being considered for installation. The system is assumed to be a $1 \mathrm{~kW}_{\mathrm{e}}$ output internal combustion engine (ICE) MCHP plant with $3,25 \mathrm{~kW}$ thermal output and consists of a 140 litres storage tank capacity (Tanaka et al. 2011) and a back-up burner. The MCHP plant runs on natural gas as a fuel source and supplies both the electricity and heat demand of the apartment. The storage tank serves as a store for thermal energy during periods of low heat demand and also to supply heat energy during periods of high thermal energy demand. If more heat is required, an additional burner can be used. Likewise, if the generated electricity does not satisfy customer's load, top-up electricity can be purchased from the utility grid.

The model was carefully developed to represent a house with an average energy consumption (neither in the lower level nor in the upper-limit of energy use) (BMU, 2009) and it is expected that this would give a good assessment of the performance of a MCHP system. A low energy demand apartment will make the idea of a MCHP less attractive and an apartment with a very high energy demand may produce over-promising results.

\section{Results and Discussion}

\subsection{Economic Assessment}

Based on the model created from the parameters of plant usage and data analysis (Table 3), it was estimated that using a MCHP in this apartment could result in annual net savings of $€$ 990. This includes benefits from avoided electricity costs, sale of excess electricity back to the grid, government support mechanisms and savings from gas costs. The costs taken into consideration for the plant usage were the extra investment cost for a micro CHP, operational costs (cost of gas) and the purchase of top-up electricity from the grid, presumably, at off peak periods. In respect to information adopted from expert knowledge, an additional investment cost of $€ 4,000$ (Houwing, 2010) is needed to install a micro CHP unit in reference to a gas fired boiler (Table 1). No data on the residual value of the system was provided; as a result, it is assumed that at the end of the useful life period, the product no longer provides any cash flow and is discontinued without any additional costs. A social discount rate (SDR) of $5 \%$ was adopted based on the recommendation of the European Commission (EC) on cost and benefit analysis (CBA) methodology in member states (EC 2014, 57). The present value (value at $t=0$ ) of the economic benefits of MCHP use for each of the year is as shown in Table 2.

Table 2. Present value calculation for each year

\begin{tabular}{llllllllllll}
\hline Year & $\mathrm{T}=0$ & $\mathrm{~T}=1$ & $\mathrm{~T}=2$ & $\mathrm{~T}=3$ & $\mathrm{~T}=4$ & $\mathrm{~T}=5$ & $\mathrm{~T}=6$ & $\mathrm{~T}=7$ & $\mathrm{~T}=8$ & $\mathrm{~T}=9$ & $\mathrm{~T}=10$ \\
\hline Cash Flow & 990 & 990 & 990 & 990 & 990 & 990 & 990 & 990 & 990 & 990 & 990 \\
\hline Present value & 990 & 942.86 & 897.96 & 855.20 & 814.48 & 775.68 & 738.75 & 703.58 & 670.05 & 638.17 & 607.77 \\
\hline
\end{tabular}

From table 2, it was estimated that a simple payback period of around 4.8 years (see table 3 for data sets) is required to recover the extra investment of $€ 4000$ needed for the installation of a MCHP unit considering a 3259 operating hours. From the manufacturer's instruction, the useful life period of a $1 \mathrm{~kW}_{\mathrm{e}}$ Ecowill ICE MCHP unit that was reviewed is 10 years (or 20,000 hours). The calculated and estimated data sets used for the economic analysis are summarized in Table 3.

Research findings, however, show that to maximize economic benefits it would be more reasonable for the investor to utilize most, if not all, of the electricity generated by the unit because the cost of purchase of grid electricity is higher than the prevalent feedback tariff as at the time this study was conducted (Note 2). With the tariff structures used in the economic assessment, the avoided grid electricity constitutes bulk of the economic advantage of plant usage whereas the applied incentives do not really contribute any significant measure to the economic feasibility of the system. In addition, during off-peak periods, the value of the generated heat by the MCHP system does not automatically offset the high cost of its electricity generation. As a result, it does not make any economic sense to keep the MCHP in operation because of the lower grid electricity tariff at these times. Thus, it would be more beneficial to shut the unit down and buy power from the grid (top-up electricity). The thermal demand can be met from the heat storage system. Under the prevailing conditions and assumptions, a total of $€ 3644.5$ extra savings in energy cost can be realized by the end of the useful life of the system. From the sensitivity analysis carried out, both the full load operating hours and unit cost of electricity have significant influence on the payback period of the project. A $10 \%$ increase in the full load operating time, reduces the payback period to 4.2 years; whereas if the operating hours decrease by $10 \%$, the payback period will increase to 5.4 years. Likewise, with a $10 \%$ rise in the electricity cost, the payback period improves to 4.3 years; whereas there is only a $6.3 \%$ increase in the payback period (from 4.8 years to 5.1 years) when the electricity cost was reduced by $10 \%$. 
Table 3. Costs and benefits parameters of plant usage

\begin{tabular}{lcc}
\hline Parameter & Value & Unit \\
\hline Average annual electricity usage & 3750 & $\mathrm{kWh}$ \\
Annual heat demand & 10590 & $\mathrm{kWh}$ \\
Running time & 3259 & $\mathrm{Hours}$ \\
Electricity generated (avoided grid electricity) & 3259 & $\mathrm{kWh}$ \\
Utilization (careful assumption based on experts' knowledge) & $70 \%(2281)$ & $\mathrm{kWh}$ \\
Efficiency of boiler (value as at time of research) & 90 & $\%$ \\
Efficiency of MCHP (value as at time of research) & 85 & $\%$ \\
Unit cost of electricity & 25,4 & $€$ cent $/ \mathrm{kWh}$ \\
Value of avoided electricity & 828 & $€$ \\
Unit cost of off-peak electricity (top-up electricity) & 5,52 & $€$ cent \\
Top-up electricity & 491 & $\mathrm{kWh}$ \\
Value of top-up electricity & 27,10 & $€$ \\
Unit value of export (average value in 2011) & 5,45 & $€$ cent $/ \mathrm{kWh}$ \\
Exported electricity & 978 & $\mathrm{kWh}$ \\
Total value of export & 53,3 & $€$ \\
Electricity bonus (stromerzeugungsbonus) for cogeneration with efficiency $>70 \%$ & 5,11 & $€$ cent/kWh \\
Total value of bonus payment & 167 & $€$ \\
Unit cost of gas & 6,39 & $€$ cent/kWh \\
Cost of gas consumed by boiler & 752 & $€$ \\
Cost of gas consumed by mCHP & 728 & $€$ \\
(less gas subsidy 0,55 €cent) & & $€$ \\
Savings in gas cost with mCHP & 24 & $€$ \\
Total Net Savings (NS) at $t=0$ & 990 & $€$ \\
Extra investment cost for the mCHP system & 4000 & $€$ \\
Simple payback period (at SDR of 5 \%) & 4.8 & Years \\
\hline
\end{tabular}

\subsection{Environmental Assessment}

Emission reduction basically depends on the fuel mix of central power production which the cogeneration system replaces as well as the efficiency of the CHP system operation and the carbon intensity of the natural gas fuel. The $\mathrm{CO}_{2}$ emission factor from burning natural gas reflects the full carbon content of the fuel under the assumption of a complete oxidation of carbon in the fuel during combustion. The default $\mathrm{CO}_{2}$ emission factor for natural gas $(56100 \mathrm{~kg} \mathrm{CO} / \mathrm{TJ}$ ) was adopted from the Intergovernmental Panel on Climate Change (IPCC) guidelines for national greenhouse gas inventories (IPCC 2006, 2.16). The average country-specific $\mathrm{CO}_{2}$ emission factor for Germany $\left(56000 \mathrm{~kg} \mathrm{CO}_{2} / \mathrm{TJ}\right)$ does not deviate much from the IPCC default emission factor (Herold 2003, 4). From the IPCC Guidelines for National Greenhouse Gas Inventories, greenhouse gas emissions from stationary combustion can be derived from the following equation:

Where:

$$
\text { Emissions }_{G H G, f u e l}=\text { Fuel Consumption }_{\text {fuel }} \cdot \text { Emission Factor }_{G H G,} \text { fuel }
$$

Emissions $_{\mathrm{GHG}, \text { fuel }}=$ the emissions of a given GHG by type of fuel (kg GHG)

Fuel Consumption $_{\text {fuel }}=$ is the amount of fuel combusted (TJ)

Emission Factor $_{\mathrm{GHG}}$, fuel $\quad=\quad$ is the default emission factor of a given GHG by fuel type (kg gas/TJ).

The fuel mix distribution for the local grid electricity generation and the corresponding $\mathrm{CO}_{2}$ emission is represented in Table 4.

Table 4. Percentage distribution of grid electricity mix

\begin{tabular}{lc}
\hline Fossil fuels & $77.6 \%$ \\
\hline Nuclear fuel & $3.2 \%$ \\
Renewable sources & $19.2 \%$ \\
$\mathrm{CO}_{2}$ emission in total $=570 \mathrm{~g} / \mathrm{kWh}(669 \mathrm{~g} / \mathrm{kWh}$ in 2015$)$ & \\
\hline
\end{tabular}

Source: SWC, 2015. 
Table 5 shows the breakdown of $\mathrm{CO}_{2}$ emissions between the various components of energy use in both the conventional and the cogeneration scenarios.

Table 5. Average balance of $\mathrm{CO}_{2}$ emissions from reference and cogeneration scenarios

\begin{tabular}{|c|c|c|c|c|}
\hline Parameter & Unit & Given data & Calculated data & Comment \\
\hline $\begin{array}{l}\text { Total } \mathrm{CO}_{2} \text { emissions from } \\
\text { centralized generation }\end{array}$ & $\mathrm{Kg} / \mathrm{kWh}$ & 0.570 & & Fuel mix emission level \\
\hline Average electricity usage & $\mathrm{kWh}$ & 3750 & & $\begin{array}{l}\text { Average electricity usage in the reference } \\
\text { scenario }\end{array}$ \\
\hline $\begin{array}{l}\text { Electricity generated by MCHP } \\
\text { system }\end{array}$ & $\mathrm{kWh}_{\mathrm{e}}$ & & 3259 & See table 3 \\
\hline Emission factor & $\mathrm{Kg} / \mathrm{TJ}$ & 56100 & & $\begin{array}{l}\text { Default IPCC } \mathrm{CO}_{2} \text { emission factor for } \\
\text { natural gas }\end{array}$ \\
\hline Condensing boiler gas & $\mathrm{kWh}$ & & 11767 & See table 3 \\
\hline consumption@90\% efficiency & $\mathrm{TJ}$ & & 0.0423612 & \\
\hline MCHP gas consumption@85\% & $\mathrm{kWh}$ & & 12459 & See table 3 \\
\hline efficiency & TJ & & 0.0448524 & \\
\hline $\begin{array}{l}\text { Annual } \mathrm{CO}_{2} \text { emissions from grid } \\
\text { electricity generation }\end{array}$ & $\mathrm{Kg} \mathrm{CO}_{2}$ & & $\begin{array}{c}0.570 \times 3750= \\
2138\end{array}$ & $\begin{array}{l}\text { Fuel mix emission level }(\mathrm{kg} / \mathrm{kWh}) \mathrm{x} \\
\text { average electricity usage }(\mathrm{kWh})\end{array}$ \\
\hline Condensing boiler emissions & $\mathrm{Kg} \mathrm{CO}_{2}$ & & $\begin{array}{c}56100 \times 0.0423612 \\
=2377\end{array}$ & $\begin{array}{l}\text { Default emission factor }(\mathrm{kg} / \mathrm{TJ}) \mathrm{x} \text { boiler } \\
\text { gas consumption }(\mathrm{TJ})\end{array}$ \\
\hline Total emission conventional & $\mathrm{Kg} \mathrm{CO}_{2}$ & & $2138+2377=4515$ & $\begin{array}{l}\text { Total annual } \mathrm{CO}_{2} \text { emissions from separate } \\
\text { generation of heat and power }\end{array}$ \\
\hline Avoided electricity & $\mathrm{kWh}$ & & 3259 & See table 3 \\
\hline $\begin{array}{l}\text { Top-up electricity (average usage - } \\
\text { avoided electricity) }\end{array}$ & $\mathrm{kWh}$ & & $3750-3259=491$ & See table 3 \\
\hline $\begin{array}{l}\text { Corresponding } \\
\text { Top-up emission }\end{array}$ & $\mathrm{Kg} \mathrm{CO}_{2}$ & & $0.570 \times 491=280$ & $\begin{array}{l}\text { Fuel mix emission level }(\mathrm{kg} / \mathrm{kWh}) \mathrm{x} \\
\text { top-up electricity }(\mathrm{kWh})\end{array}$ \\
\hline $\begin{array}{l}\text { Emissions from MCHP heat } \\
\text { generation }\end{array}$ & $\mathrm{Kg} \mathrm{CO}_{2}$ & & $\begin{array}{c}56100 \mathrm{x} \\
0.0448524=2516.2\end{array}$ & $\begin{array}{l}\text { Default emission factor }(\mathrm{kg} / \mathrm{TJ}) \times \text { micro } \\
\text { CHP gas consumption }(\mathrm{TJ})\end{array}$ \\
\hline Total emission MCHP & $\mathrm{Kg} \mathrm{CO}_{2}$ & & $\begin{array}{c}2516.2+280= \\
2796.2\end{array}$ & $\begin{array}{l}\text { Total } \mathrm{CO}_{2} \text { emissions from cogeneration } \\
\text { system. }\end{array}$ \\
\hline $\begin{array}{l}\mathrm{CO}_{2} \text { emission reduction ratio } \\
(\mathrm{ERR})\end{array}$ & $\%$ & $\begin{array}{c}\mathrm{ERR}=\left(\mathrm{E}_{\mathrm{con}}-\mathrm{E}_{\mathrm{CHP}}\right) \\
/ \mathrm{E}_{\mathrm{con}} \times 100 \%\end{array}$ & 38.1 & \\
\hline
\end{tabular}

From the environmental assessment carried out (Table 5), the MCHP system produced more onsite $\mathrm{CO}_{2}$ emissions (2516.2 $\mathrm{kg} \mathrm{CO}_{2}$ per year) compared to the condensing boiler $\left(2377 \mathrm{~kg} \mathrm{CO}_{2}\right.$ per year). This is as a result of the higher operational efficiency of the condensing gas boiler. However, when compared to the baseline scenario of separate generation of heat and power, the $\mathrm{CO}_{2}$ emissions from annual energy consumption could be reduced by as much as $38.1 \%$ when the average grid mix electricity is replaced with a $1 \mathrm{~kW}_{\mathrm{e}}$ ICE MCHP system (1719 $\mathrm{kg} \mathrm{CO}_{2}$ per year, equivalent to offsetting the annual Greenhouse Gas (GHG) emissions from 4,093 miles driven by an average passenger vehicle). The obtained result is comparable to estimates $(20-40 \%)$ given in a study by Pehnt et al. (2006).

\section{Conclusion and Recommendations}

The results obtained from this paper show that MCHP systems offer a good replacement for conventional gas boilers with potential for emission reduction and energy cost savings. However, their high initial cost hampers market diffusion. With improved support mechanisms to reduce initial cost or reduction in manufacturers' cost due to economies of scale, MCHP systems could become more attractive to end users. At the same time, this research work did not carry out the economic valuation of other benefits from the use of MCHP system, such as emission reduction, savings in capital intensive grid expansion projects, etc. It was largely focused on the immediate costs and benefits of system operation. 
Since combustion is not the only source of greenhouse gases, a complete Life Cycle Assessment (LCA) is recommended in order to study a comprehensive environmental benefit of cogeneration. The operational efficiency of the MCHP systems will determine the magnitude of emission and cost savings. Thus, technology advancement to improve the efficiency of the system operation will maximize both economic and environmental benefits.

\section{Notes}

Note 1. Efficiency of the MCHP unit adopted as at the time of research. However, presently systems with efficiency levels of 90 per cent are available.

Note 2. The observed current electricity price of 26.93 €cent per kWh (SWC, 2015) effective from 1 March, 2015, does not deviate much from the value of 25.4 €cent per $\mathrm{kWh}$ which was adopted in the economic assessment in table 3 and prevalent as at the time of research.

\section{References}

Amecke, H., Deason, J., Hobbs, A., Novikova, A., Xiu, Y., \& Shengyuan. Z. (2013). Buildings energy efficiency in China, Germany, and the United States. San Francisco: Climate Policy Initiative. Retrieved from http:/climatepolicyinitiative.org/wp-content/uploads/2013/04/Buildings-Energy-Efficiency-in-China-Germ any-and-the-United-States.pdf

Arbeitsgemeinschaft für Sparsamen und Umweltfreundlichen Energieverbrauch e.V. (2008). Power-generating heating systems: Opportunities for improving energy efficiency. Kaiserslautern. Retrieved from http://www.gerg.eu/public/uploads/files/publications/brochures/brochure_asue.pdf

Bundesamt für Wirtschaft und Ausfuhrkontrolle - Federal Office for Economic Affairs and Export Control. (2012). KWK $\quad-\quad$ Zuschlag: $\quad$ KWKG $2012 . \quad$ Retrieved from www.bafa.de/bafa/de/energie/kraft_waerme_kopplung/stromverguetung/kwk-anlagen_bis_50kw/kwk_zusc hlag/index.html

Bundesministerium für Umwelt, Naturschutz, Bau und Reaktorsicherheit - Federal Ministy for the Environment, Nature conservation, Building and Nuclear Safety. (2009). Heizspiegel Cottbus 2009: Vergleichswerte zu Heizenergieverbrauch, Heizkosten und $\mathrm{CO}_{2}$-Emissionen. Stadt Cottbus. Retrieved from www.heizspiegel.de/fileadmin/hs/heizspiegel/khsp/cottbus/heizspiegel-cottbus-web.pdf

Cogeneration Europe. (2005). The European association for the promotion of cogeneration. News archive.

European Commission. (2004). "Directive 2004/8/EC of the European Parliament and of the Council of 11 February 2004 on the Promotion of Cogeneration based on a Useful Heat Demand in the Internal Energy Market and Amending Directive 92/42/EEC." Official Journal of the European Union, 47(52), 50-60.

European Commission. (2014). Guide to cost-benefit analysis of investment projects: Economic appraisal tool for cohesion policy 2014 - 2020. December 2014. Brussels: Belgium. European Commission Directorate-General for Regional and Urban policy. Retrieved from http://www.ec.europa.eu/regional_policy/sources/docgener/studies/pdf/cba_guide.pdf

Herold, A. (2003). Comparison of CO2 emission factors for fuels used in greenhouse gas inventories and consequences for monitoring and reporting under the EC emissions trading scheme. ETC/ACC Technical Paper 2003/10. Bilthoven, the Netherlands: European Topic Centre on Air and Climate Change. Retrieved from http://acm.eionet.europa.eu/docs/ETCACC_TechnPaper_2003_10_CO2_EF_fuels.pdf

Houwing, M. (2010). Smart heat and power: Utilizing the flexibility of micro cogeneration. Delft, the Netherlands: Next Generation Infrastructures Foundation.

IEA/ECBCS Annex 42. (2004). FC+COGEN-SIM The simulation of building-integrated fuel cell and other cogeneration systems - Annex text. Retrieved from cogen-sim.net/

Intergovernmental Panel on Climate Change. (2006). Guidelines for national greenhouse gas inventories. Retrieved

from http://www.ipcc-nggip.iges.or.jp/public/2006gl/pdf/2_Volume2/V2_2_Ch2_Stationary_Combustion.pdf

Paschotta, R. (2016). “RP-Energie-Lexikon” RP photonics consulting. Accessed March 2. Retrieved from http://www.energie-lexikon.info/warmwasser.html

Pehnt, M., Cames, M., Fischer, C., Praetorius, B., Schneider, L., \& Schumacher, K. (2006). Micro cogeneration: towards decentralized energy systems. Berlin: Springer. https://doi.org/10.1007/3-540-30821-0_1 
Ren, H., \& W. Gao. (2010). "Economic and Environmental Evaluation of micro CHP systems with different operating modes for Residential Buildings in Japan.” Energy and Building 42 (2010): 853-861 https://doi.org/10.1016/j.enbuild.2009.12.007

Ren, H., Gao, W., \& Ruan, Y. (2007). Study of different micro CHP alternatives for residential application. Retrieved from http://inive.org/members_area/medias/pdf/Inive\%5CIAQVEC2007\%5CRen.pdf

Stadtwerk Cottbus Rev. Code Ann. $\S 42 \quad$ (2005). Retrieved from www.stadtwerke-cottbus.de/index.php?option=com_content\&view=article\&id=76\&Itemid=223

Tanaka, H., Suzuki, A., Yamamoto, K., Yamamoto, I., Yoshimura, M., \& Togawa, K. (2011). New ECOWILLA new cogeneration gas engine micro CHP. Japan: International Gas Union Research Conference. Retrieved from http://members.igu.org/old/IGU\%20Events/igrc/igrc2011/igrc-2011-proceedings-and-presentations/poster-p apers-session-3/P3-56_Hiroki\%20Tanaka.pdf

United States Environmental Protection Agency. (2013). CHP: Efficiency benefits. Retrieved from http://www.epa.gov/chp/basic/efficiency.html

Uyterlinde, M.A., van Sambeek, E.J.W., \& Cross, E.D. (2002). Decentralized generation: Development of EU policy. Report in the Framework of the DECENT Project. Petten, the Netherlands: Energy Research Centre of the Netherlands. Retrieved from http://ecn.nl/docs/library/report/2002/c02075.pdf

\section{Copyrights}

Copyright for this article is retained by the author(s), with first publication rights granted to the journal.

This is an open-access article distributed under the terms and conditions of the Creative Commons Attribution license (http://creativecommons.org/licenses/by/4.0/). 